\title{
Presence of functional cannabinoid receptors in human endocrine pancreas
}

\author{
F. J. Bermúdez-Silva $\cdot$ J. Suárez $\cdot$ E. Baixeras • \\ N. Cobo • D. Bautista • A. L. Cuesta-Muñoz • \\ E. Fuentes • P. Juan-Pico • M. J. Castro • G. Milman • \\ R. Mechoulam • A. Nadal • F. Rodríguez de Fonseca
}

Received: 11 July 2007 / Accepted: 12 October 2007 / Published online: 19 December 2007

(C) Springer-Verlag 2007

\begin{abstract}
Aims/hypothesis We examined the presence of functional cannabinoid receptors 1 and 2 (CB1, CB2) in isolated human islets, phenotyped the cells producing cannabinoid receptors and analysed the actions of selective cannabinoid receptor agonists on insulin, glucagon and somatostatin secretion in vitro. We also described the localisation on islet cells of: (1) the endocannabinoid-producing enzymes $\mathrm{N}$ -
\end{abstract}

Electronic supplementary material The online version of this article (doi:10.1007/s00125-007-0890-y) contains supplementary material, which is available to authorised users.

F. J. Bermúdez-Silva $(\bowtie) \cdot J$. Suárez $\cdot$ E. Baixeras $\cdot$ N. Cobo $\cdot$

A. L. Cuesta-Muñoz $\cdot$ F. Rodríguez de Fonseca $(\square)$

Fundación IMABIS, Hospital Carlos Haya,

Avenida Carlos Haya 82, $7^{\text {a }}$ Planta, Pabellón A,

29010 Málaga, Spain

e-mail: franciscoj.bermudez@fundacionimabis.org

e-mail: fernando.rodriguez@fundacionimabis.org

D. Bautista

Servicio de Anatomía Patológica, Hospital Carlos Haya,

Málaga, Spain

E. Fuentes $\cdot$ P. Juan-Pico $\cdot$ A. Nadal

Instituto de Bioingeniería, Universidad Miguel Hernández,

Elche, Spain

\section{J. Castro}

Servicio de Cirugía General y Digestiva, Hospital Carlos Haya,

Málaga, Spain

G. Milman $\cdot$ R. Mechoulam

Department of Medicinal Chemistry and Natural Products,

Ein Kerem Campus, Hebrew University,

Jerusalem, Israel acyl-phosphatidyl ethanolamine-hydrolysing phospholipase D and diacylglycerol lipase; and (2) the endocannabinoiddegrading enzymes fatty acid amidohydrolase and monoacyl glycerol lipase.

Methods Real-time PCR, western blotting and immunocytochemistry were used to analyse the presence of endocannabinoid-related proteins and genes. Static secretion experiments were used to examine the effects of activating $\mathrm{CB} 1$ or $\mathrm{CB} 2$ on insulin, glucagon and somatostatin secretion and to measure changes in 2-arachidonoylglycerol (2-AG) levels within islets. Analyses were performed in isolated human islets and in paraffin-embedded sections of human pancreas.

Results Human islets of Langerhans expressed $C B 1$ and $C B 2$ (also known as CNR1 and CNR2) mRNA and CB1 and $\mathrm{CB} 2$ proteins, and also the machinery involved in synthesis and degradation of 2-AG (the most abundant endocannabinoid, levels of which were modulated by glucose). Immunofluorescence revealed that CB1 was densely located in glucagon-secreting alpha cells and less so in insulin-secreting beta cells. CB2 was densely present in somatostatin-secreting delta cells, but absent in alpha and beta cells. In vitro experiments revealed that CB1 stimulation enhanced insulin and glucagon secretion, while CB2 agonism lowered glucose-dependent insulin secretion, showing these cannabinoid receptors to be functional.

Conclusions/interpretation Together, these results suggest a role for endogenous endocannabinoid signalling in regulation of endocrine secretion in the human pancreas.

Keywords Anandamide ·2-Arachidonoylglycerol ·

Beta cell $\cdot$ Cannabinoid receptors .

Fatty acid amidohydrolase · Glucagon · Human · Insulin .

Islets of Langerhans $\cdot$ Somatostatin 


\begin{tabular}{|c|c|}
\hline \multicolumn{2}{|c|}{ Abbreviations } \\
\hline AEA & anandamide \\
\hline ACEA & arachidonoyl-2'-chloroethylamide \\
\hline $2-A G$ & 2-arachidonoyl glycerol \\
\hline AM251 & $\begin{array}{l}N \text {-(piperidin-1-yl)-5-(4-iodophenyl)-1- } \\
\text { (2,4-dichlorophenyl)-4-methyl-1H-pyrazole- } \\
\text { 3-carboxamide }\end{array}$ \\
\hline $\mathrm{CB} 1$ & cannabinoid receptor 1 \\
\hline $\mathrm{CB} 2$ & cannabinoid receptor 2 \\
\hline DAGL & diacylglycerol lipase \\
\hline FAAH & fatty acid amidohydrolase \\
\hline IEQ & islet equivalent \\
\hline JWH 133 & $\begin{array}{l}\text { 3-(1',1'-dimethylbutyl)-1-deoxy- } \\
\Delta^{8} \text {-tetrahydrocannabinol }\end{array}$ \\
\hline MAGL & monoacyl glycerol lipase \\
\hline NAPE-PLD & $\begin{array}{l}N \text {-acyl-phosphatidyl ethanolamine- } \\
\text { hydrolysing phospholipase D }\end{array}$ \\
\hline
\end{tabular}

\section{Introduction}

The endogenous cannabinoids, i.e. the endocannabinoids anandamide (AEA) and 2-arachidonoyl glycerol (2-AG), are lipid transmitters that were identified in the brain as relevant modulators of synaptic transmission [1-4]. They act through different receptors (cannabinoid receptors 1 and 2 [CB1, CB2]) and are produced through specific enzymes (diacylglycerol lipase [DAGL] $\alpha$ and $\beta$, for $2-\mathrm{AG}$ and $N$ - acyl-phosphatidyl ethanolamine-hydrolysing phospholipase D [NAPE-PLD] for AEA) and degraded by at least two different enzymes (fatty acid amidohydrolase [FAAH] and monoacyl glycerol lipase [MAGL]) [5] (Fig. 1). In addition to the physiological role of these transmitters in the central nervous system, recent studies have established their functionality in peripheral organs involved in feeding control, energy homeostasis and metabolism [6-8]. Endocannabinoids counteract satiety signals at both the gastrointestinal and hypothalamic levels and promote overfeeding, as well as lipid biosynthesis and storage [7-12].

The endocannabinoids are relevant homeostatic signals whose dysregulation contributes to obesity and type 2 diabetes $[6,13]$. A clinical trial in obese patients treated with Rimonabant, a CB1 antagonist, resulted in effective reduction in body weight, waist circumference and insulin resistance [14, 15]. Additional studies demonstrated that CB1 blockade improves insulin resistance, insulinaemia and glycosylated haemoglobin in obese patients with type 2 diabetes [16]. Since these actions are not totally explained by the weight loss induced by the anorectic actions derived from CB1 blockade, the endocannabinoids may also modulate metabolism in peripheral organs. This hypothesis has been confirmed in animal models where CB1 were found to modulate lipid and glucose metabolism in insulinsensitive tissues such as the adipose tissue [7] and the liver [12]. Recent studies extended this notion to the endocrine pancreas, where the endogenous cannabinoid system has

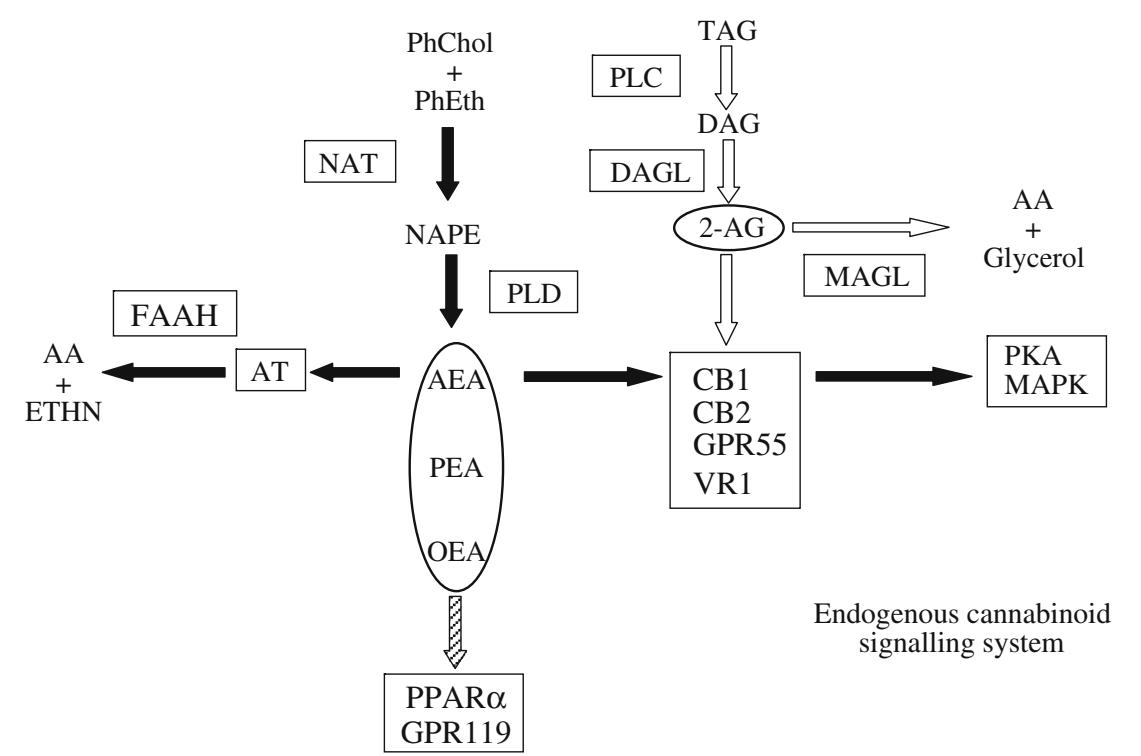

Fig. 1 Endogenous cannabinoid signalling system. The two main endocannabinoids are AEA and 2-AG. They act mainly through CB1 and $\mathrm{CB} 2$. The parents acylethanolamides palmitoylethanolamide (PEA) and oleoylethanolamide (OEA) act through different receptor systems (the orphan receptor GPR119 and the peroxisome proliferator activated-receptor alpha $[\operatorname{PPAR} \alpha])$. We examined the presence of functional $\mathrm{CB} 1$ and $\mathrm{CB} 2$ in isolated human islets, as well as the localisation of AEA-producing enzyme NAPE-PLD, AEA-degrading enzyme FAAH and the enzymes involved in generation (DAGL) and degradation (MAGL) of 2-AG in sections of human pancreas. AA, arachidonic acid, DAG, diacylglycerol; ETHN, ethanolamide; MAPK, mitogen-activated protein kinase; PhChol, phosphatidyl choline; PhEth, phosphatidyl ethanolamine; PKA, protein kinase A; PLC, phospholipase C; PLD, phospholipase D; TAG, triacylglycerol, VR1, vanilloid receptor 1 
recently been identified in mice, rats and the rat insulinoma beta cell line RIN-m5F [17-20]. Whereas stimulation of CB1 in the rat leads to glucose intolerance, activation of CB2 improves glucose handling after a glucose load [18, 19]. In mice, CB2 modulate calcium oscillations and insulin secretion in vitro [17]. These actions are derived from glucose-induced alterations in endocannabinoid production, as demonstrated in the pancreatic beta cell line RIN-m5F. Thus, elevations of glucose concentration in the culture media are associated with a rise in the levels of both 2-AG and AEA [20].

To date, no studies have addressed the presence and functional significance of cannabinoid receptors in human endocrine pancreas. However, the clear and conclusive effects of chronic treatment with the CB1 antagonist Rimonabant on insulin resistance in obese humans, with or without type 2 diabetes, clearly suggest the presence of this system in human pancreatic islets [14-16]. In order to confirm this hypothesis, we examined the presence of functional $\mathrm{CB} 1$ and $\mathrm{CB} 2$ in isolated human islets, as well as the localisation of the machinery for synthesis and degradation of endocannabinoids in human pancreatic tissue.

\section{Methods}

Human islet isolation Islets were isolated and purified from human pancreases using the Ricordi method [21, 22]. The present studies were performed in pancreas from four braindead, heart-beating, non-diabetic, non-obese (mean BMI $28.3 \pm 0.7 \mathrm{~kg} / \mathrm{m}^{2}$ ) adult organ donors (mean age $50 \pm$ 14 years; two women, two men). Cause of death was stroke for two donors and anoxic encephalopathy for the other two. All procedures were performed according to specific legal guidelines and written informed consent was obtained from each donor's family; the local ethics committee of Carlos Haya Hospital approved and supervised the experiments.

The pancreas was cut into two parts, cannulated and perfused with cold $\left(4-8^{\circ} \mathrm{C}\right)$ liberase (Liberase-HI; Roche Molecular Biochemical, Indianapolis, IN, USA). After perfusion, the pancreas was minced, transferred to the Ricordi chamber and digestion carried out at $37^{\circ} \mathrm{C}$. Digestion was stopped and the digest diluted with 2 litres dilution solution (Mediatech Cellgro, Herndon, VA, USA). The digest was collected and centrifuged for $3 \mathrm{~min}$ at $1,000 \mathrm{rpm}(225 \mathrm{~g})$ and $4^{\circ} \mathrm{C}$. Pellets were washed and recombined in cold modified University of Wisconsin solution. The tissue digest was purified on a continuous ficoll (Biochrom, Berlin, Germany) density gradient, using the Cobe 2991 cell separator/processor (Gambro, Lakewood, CO, USA).
Table 1 mRNA expression of $C B 1$ and $C B 2$

\begin{tabular}{lll}
\hline & $C B 1: \beta$-actin $\left(\times 10^{-4}\right)^{\mathrm{a}, \mathrm{b}}$ & $C B 2: \beta$-actin $\left(\times 10^{-4}\right)^{\mathrm{a}, \mathrm{b}}$ \\
\hline Cerebellum & $8.63 \pm 1.07$ & $0.0191 \pm 0.0010$ \\
Islets & $2.95 \pm 0.81$ & $0.0224 \pm 0.0110$ \\
Leucocytes & $0.0148 \pm 0.0001$ & $1.86 \pm 0.56$ \\
\hline
\end{tabular}

Islet data are mean $\pm \mathrm{SD}$ from three different donors. Data from human cerebellum and leucocytes are mean $\pm \mathrm{SD}$ from triplicate measurement of commercially available total RNA reference samples.

${ }^{\text {a }}$ Real-time PCR quantification of $C B 1$ and $C B 2 \mathrm{cDNA}$ using specific primers: a comparative analysis of the expression of both cannabinoid receptors in human islets was done using total RNA reference samples from human cerebellum and leucocyte commercial standards

${ }^{\mathrm{b}} C B 1$ expression is about 100 -fold higher than that of $C B 2$ in human islets and threefold less than in CB1-enriched tissue, the cerebellum

The fraction containing the purified islet mass was analysed and the purity of the preparation assessed with dithizone. The preparations used in this study had more than $80 \%$ purity. Fresh aliquots of 1,000 islet equivalents (IEQs) were snap-frozen for subsequent mRNA quantification and western blotting analysis. The remaining purified islets were cultured at 30,000 IEQs per $75 \mathrm{~cm}^{2}$ non-treated flask (Nunc, Wiesbaden, Germany) in a final volume of

Fig. 2 Double immunofluorescence of cannabinoid receptors and insulin, glucagon and somatostatin. Representative photomicrographs of sections through a human pancreas showing the same area immunolabelled for both $\mathrm{CB} 1$ and $\mathrm{CB} 2$ (red), and for insulin, glucagon and somatostatin (green), with merged images in (yellow). a Immunostaining of cells in a pancreatic islet with an antiserum against CB1. Note that most of these cells have a typical morphology of alpha cells (arrowheads), with small diameter and big nucleus. b Islet cells stained in green are insulin-containing beta cells. c Colocalisation of insulin and CB1. Note that most CB1-containing cells do not produce insulin, so they are non- $\beta$ cells (arrowheads). However, some cells have co-production of insulin and CB1 (arrows). d Immunostaining of pancreatic cells with an antiserum against CB2. Exocrine tissue has high CB2 production, but only scattered cells in islets are CB2-positive (arrowheads). e Islet cells stained in green are insulin-containing beta cells. f Merged image (d) and (e). CB2producing cells in the pancreatic islets do not show insulin immunoreactivity. $\mathbf{g}$ Immunostaining of cells in a pancreatic islet with an antiserum against CB1. $\mathbf{h}$ Islet cells stained in green are glucagoncontaining alpha cells. i Double staining with glucagon and CB1. Nearly all alpha cells produce CB1 (yellow). j Immunostaining of pancreatic cells with an antiserum against CB2. $\mathbf{k}$ Islet cells stained in green are glucagon-containing alpha cells. I Merged image of (j) and (k) clearly showing that CB2-containing cells in the pancreatic islet are not alpha cells. $\mathbf{m}$ Immunostaining of cells in a pancreatic islet with an antiserum against CB1. n Islet cells stained in green are scattered cells containing somatostatin. o Double staining with somatostatin and CB1. Nearly all delta cells are immunonegative for CB1. p Immunostaining of pancreatic cells with an antiserum against CB2. q Islet cells stained in green are somatostatin-containing delta cells, some with a high intensity. $\mathbf{r}$ Merged images of (p) and (q) clearly show that delta cells preferentially produce CB2. Scale, as indicated 


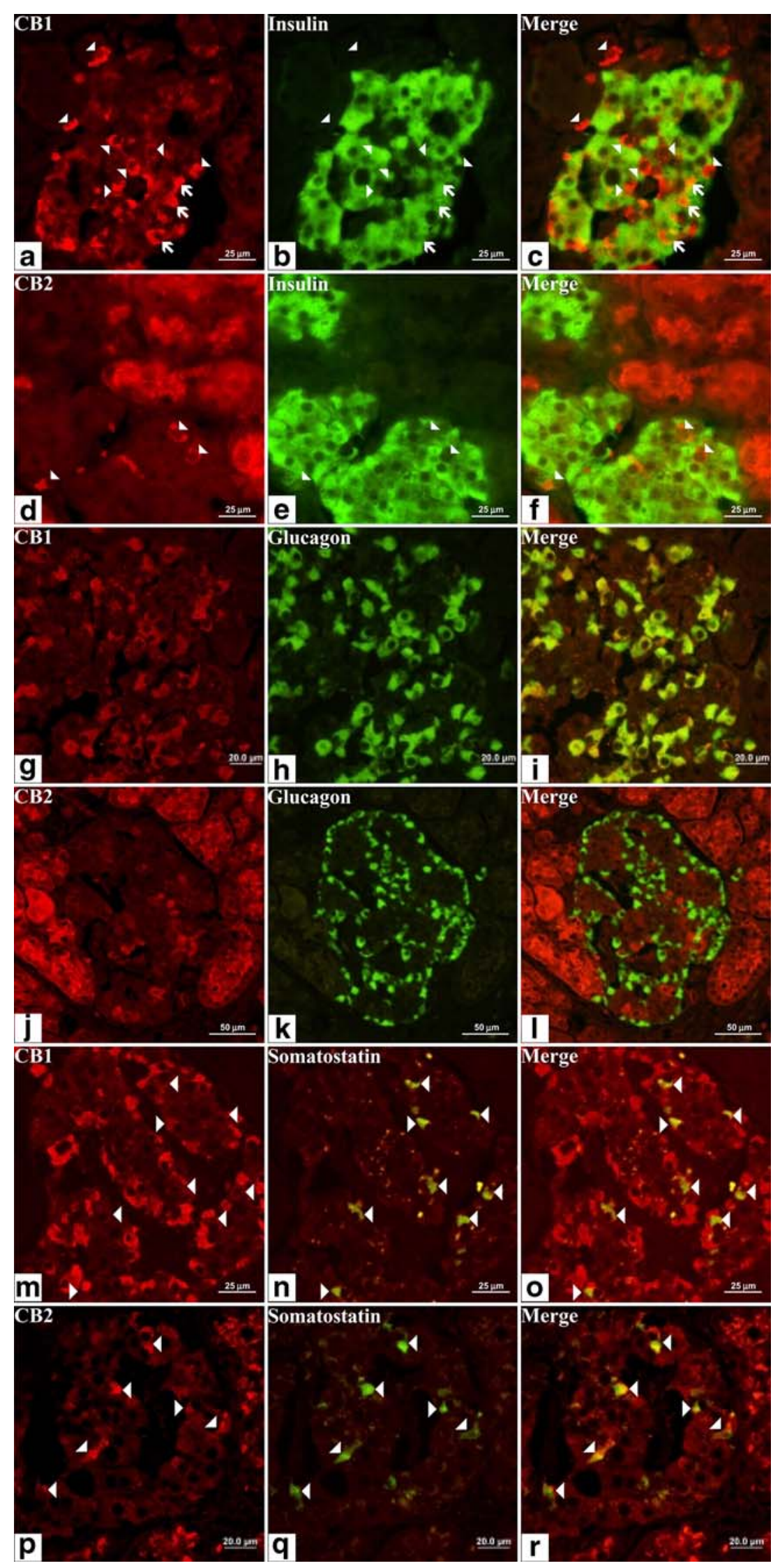


$30 \mathrm{ml}$ CMRL-1066 medium (Mediatech Cellgro) supplemented with $10 \% \mathrm{FCS}(v / v), 100 \mathrm{IU} / \mathrm{ml}$ penicillin, $100 \mu \mathrm{g} /$ $\mathrm{ml}$ streptomycin, $2.8 \mu \mathrm{g} / \mathrm{ml}$ amphotericin and $2 \mathrm{mmol} / \mathrm{l}$ L-glutamine; this was done for 3 to 5 days at $37^{\circ} \mathrm{C}, 95 \%$ relative humidity and $5 \% \mathrm{CO}_{2}$. Culture medium was replaced every 2 days. After 3 to 5 days of culture the preparations were checked for viability by Trypan Blue exclusion test and found to contain $<5 \%$ damaged cells.

Immunohistochemistry in human pancreas samples Immunohistochemical and immunofluorescence studies were performed in human pancreatic tissue obtained from the Pathology Department tissue bank at Carlos Haya Hospital. Biopsy samples were taken from four different nondiabetic, non-obese (mean BMI $27.5 \pm 1.5 \mathrm{~kg} / \mathrm{m}^{2}$ ) adult patients (mean age $68 \pm 9$ years; three women, one man) with pancreatic adenocarcinoma (non-endocrine tumour). All procedures were performed according to specific legal guidelines and written informed consent were obtained from patients; the local ethics committee of Carlos Haya Hospital approved and supervised the experiments. See additional information in Electronic supplementary material (ESM).

NAPE-PLD-, DAGL $\alpha$ - and DAGL $\beta$-specific antibody generation Polyclonal rabbit antibodies were generated against cannabinoid machinery proteins as described in ESM. Immunising peptides were: (1) a 13-amino acid peptide comprising part of both the C-terminal and the $\mathrm{N}$-terminal region of NAPE-PLD (MDENSCDKAFEET); (2) a 16amino acid peptide from the C-terminal region of DAGL $\alpha$ (CGASPTKQDDLVISAR); and (3) a 16-amino acid peptide from an internal sequence of DAGL $\beta$ (SSDSPLD SPTKYPTLC). Extensive validation studies of these antibodies as immunocytochemistry markers were performed in brain samples (ESM Fig. 1).

Double immunofluorescence and immunohistochemistry Paraffin-embedded sections of human pancreases were analysed for the presence of CB1, CB2 and FAAH in alpha (glucagon), beta (insulin) and delta (somatostatin) pancreatic islet cells by double immunofluorescence. Sections were incubated overnight at room temperature with mouse anti-insulin (dilution 1:200; Sigma-Aldrich Quimica S.A., Madrid, Spain), anti-glucagon (1:200; Sigma) or antisomatostatin (1:200; Genetex, San Antonio, TX, USA) antibody and a rabbit anti-CB1 (dilution 1:100; ABRAffinity Bioreagents, Golden, CO, USA), anti-CB2 (1:100; ABR) or anti-FAAH (1:50; Cayman Chemical, Ann Arbor, MI, USA) antibody. After extensive washes in PBS, the sections were incubated for $2 \mathrm{~h}$ at room temperature in a secondary anti-mouse IgG-FITC antibody (dilution 1:200; Sigma) and a secondary anti-rabbit IgG-Cy3 antibody
(1:300; Jackson Immunoresearch Laboratories, West Grove, PA, USA). Finally, the sections were washed in PBS and analysed under epifluorescence microscopy (Olympus Europa, Hamburg, Germany). Additional immunohistochemistry studies were done to determine the levels of NAPE-PLD, DAGL $\alpha$, DAGL $\beta$, FAAH, MAGL, insulin and chromogranin A. In all cases, the specificity of the immunostaining was confirmed by omission of the first antibody or the use of preadsorption of primary antibodies with the immunising peptide. Digital photographs were taken with an Olympus BX41 microscope (Olympus).

Real-time quantitative PCR Real-time quantitative PCR was used to measure $C B 1$ (also known as $C N R$ ), $C B 2$ (also known as CNR2) and NAPE-PLD mRNA expression according to Hansson et al. [23]. Briefly, total RNA was isolated from snap-frozen pellets containing 1,000 IEQs from three different donors by using Trizol reagent (Gibco BRL Life Technologies, Baltimore, MD, USA). All RNA samples had A260:280 ratios of 1.8 to 2.0. Total RNA from each sample and random hexamers were used to generate first strand cDNA using transcriptor reverse transcriptase (Roche Applied Science, Indianapolis, IN, USA). Negative controls included reverse transcription reactions omitting reverse transcriptase. The cDNA obtained was used as the template for real-time quantitative PCR with an iCycler system (Bio-Rad, Hercules, CA, USA) using the QuantiTect SYBR Green PCR kit (Qiagen, Hilden, Germany). A comparative analysis of the expression of both cannabinoid receptors in human islets was made using reference total RNA samples from commercial standards of both human cerebellum and human leucocytes (BD Biosciences, Palo Alto, CA, USA). Primers for PCR reactions and annealing temperatures are shown in the ESM. Quantification was carried out with a standard curve run at the same time as the samples with each reaction run in duplicate. Absolute values from each sample were normalised with regard to beta actin.

Western blot analysis Frozen cell pellets from human pancreatic islets (1,000 IEQs) were suspended in $50 \mu \mathrm{l}$ SDS sample buffer containing dithiothreitol and heatdenatured for $5 \mathrm{~min}$ at $95^{\circ} \mathrm{C}$. For immunoblotting, equal amounts of protein from lysates $(10 \mu \mathrm{l}$ per lane $)$ were subjected to $7.5 \%(w / v)$ SDS-PAGE and homogeneous transfer to nitrocellulose membranes controlled by Ponceau red staining. Blots were preincubated for $1 \mathrm{~h}$ at room temperature with PBS containing $0.1 \%(v / v)$ Tween 20 and $2 \%(w / v)$ albumin fraction $\mathrm{V}$ from bovine serum (blocking buffer). For protein detection, each blotted membrane lane was incubated separately with the specific CB1 (1:250; ABR), CB2 (1:250; ABR), FAAH (1:100; Cayman), MAGL (1:500; kindly donated by D. Piomelli, Department of Pharmacology, University of California, Irvine, CA, USA), DAGL $\alpha$ (1:100), 
DAGL $\beta$ (1:100) and NAPE-PLD (1:75) antibodies from rabbit, diluted in PBS containing 0.1\% $(v / v)$ Tween 20 and $2 \%(w / v)$ albumin fraction $\mathrm{V}$ from bovine serum. This was done overnight at room temperature. The specific protein bands were visualised using the enhanced chemiluminescence technique (Amersham International, Amersham, UK) and an imaging system (Auto-Biochem; LTF Labortechnik, Wasserburg/Bodensee, Germany). Western blots showed that each primary antibody detected a protein of the expected molecular size. As additional controls, blotted membrane lanes were incubated with the primary antibody preadsorbed with the corresponding immunising peptide.

Static secretion of insulin, glucagon and somatostatin in isolated islets After 5 days in vitro, total IEQs and acinar contamination were determined by staining with dithizone. Viability was checked by Trypan Blue exclusion. Less than $5 \%$ of cells within each islet were non-viable and no acinar tissue was adhered. Human cultured islets were then washed with Hanks' solution and suspended in a serumfree medium. Groups of 50 IEQs were plated on sterile 24well plates (Nunc) with $1 \mathrm{ml}$ medium containing (mmol/l): $115 \mathrm{NaCl}, 10 \mathrm{NaHCO}_{3}, 5 \mathrm{KCl}, 1.1 \mathrm{MgCl}_{2}, 1.2 \mathrm{NaH}_{2} \mathrm{PO}_{4}$, $2.5 \mathrm{CaCl}_{2}$ and $25 \mathrm{HEPES}$; plus $1 \%$ albumin and either $3 \mathrm{mmol} / \mathrm{l}$ or $11 \mathrm{mmol} / \mathrm{l}$ glucose. Additionally, one of the following drugs was added to the medium (Tocris Bioscience, Bristol, UK): $2-\mathrm{AG}\left(10^{-5}\right.$ to $\left.10^{-6} \mathrm{~mol} / \mathrm{l}\right)$; AEA $\left(10^{-8}\right.$ to $10^{-7} \mathrm{~mol} / \mathrm{l}$ ); arachidonyl-2'-chloroethylamide (ACEA), a specific CB1 activator [24] $\left(10^{-7}\right.$ to $\left.10^{-9} \mathrm{~mol} / \mathrm{l}\right)$; $3-\left(1^{\prime}, 1^{\prime}-\right.$ dimethylbutyl)-1-deoxy- $\Delta^{8}$-tetrahydrocannabinol (JWH 133), a specific CB2 activator [25] $\left(10^{-7}-10^{-9} \mathrm{~mol} / \mathrm{l}\right)$; or $N$-(piperidin-1-yl)-5-(4-iodophenyl)-1-(2,4-dichlorophenyl)4-methyl-1H-pyrazole-3-carboxamide (AM251), a selective CB1 antagonist [26] $\left(10^{-7} \mathrm{~mol} / \mathrm{l}\right)$. Concentrations of cannabinoid receptor agonists and antagonists were selected according to the reported $K_{\mathrm{i}}$ value of each compound. Each experimental condition was assayed in quadruplicate and islets isolated from four different donors were employed. The islets were incubated at $37^{\circ} \mathrm{C}$ and $5 \% \mathrm{CO}_{2}$ for $1 \mathrm{~h}$, after which the medium containing the islets was collected in $1.5 \mathrm{ml}$ tubes with $520 \mathrm{kIU}$ aprotinin and centrifuged for $5 \mathrm{~min}$ at $1,000 \times \mathrm{g}$ and $4^{\circ} \mathrm{C}$. The supernatant fractions were divided into aliquots and stored at $-80^{\circ} \mathrm{C}$ for further quantification of insulin, glucagon and somatostatin by means of specific commercial radioimmunoassays or enzyme immunoassay kits. The cellular pellets were frozen at $-80^{\circ} \mathrm{C}$ to measure total protein amount (see ESM). Secretion of insulin, glucagon and somatostatin from each well was normalised with the protein content of their 50 IEQs.

Analysis of islet 2-AG levels Because the immunohistochemical analysis revealed that the islets contained the machinery for synthesis and degradation of $2-\mathrm{AG}$ but not
AEA, we measured intracellular levels of 2-AG in islets incubated either in low $(3 \mathrm{mmol} / \mathrm{l})$ or high $(11 \mathrm{mmol} / \mathrm{l})$ glucose concentrations. Seven-hundred IEQs per well were incubated and $1 \mathrm{~h}$ after incubation islets were centrifuged and assayed in triplicate for 2-AG content using quantitative GCMS in a TRACE GC/MS 2000 system with electron impact ionisation detector (Finnigan, San Jose, CA, USA; see ESM).

Statistical analysis Results are expressed as the mean \pm SEM. The significance of differences between the groups was evaluated by either Student's $t$ test (two-tailed, paired groups) or one-way ANOVA followed by Newman-Keuls test as post hoc (multiple group comparison). A $p$ value of $<0.05$ was considered significant.

\section{Results}

Human islets express $C B 1$ and $C B 2 m R N A C B 1$ and $C B 2$ mRNAs are present in fresh isolated islets. Table 1 shows that $C B 1$ expression was almost 100-fold higher than that of $C B 2$ in human islets and threefold lower than that of a $\mathrm{CB} 1$ enriched tissue, the cerebellum. $C B 2$ expression was 80-fold lower than a CB2-enriched tissue, the leucocytes. Despite the presence of exocrine tissue on the islet pellets used for mRNA isolation, immunoreactivity to CB2 antibody within the islets supports the expression of $C B 2$ mRNA in endocrine tissue in a specific small population of cells.

Double immunofluorescence revealed the cell subtype containing both CB1 and CB2 in human islets Cannabinoid receptors had a specific distribution pattern in human islet cells. Figure $2 \mathrm{a}-\mathrm{f}$ depicts the double immunofluorescence of cannabinoid receptors and insulin. Only a small portion of beta cells produced CB1 (Fig. 2c), the majority of CB1positive cells being insulin-negative. Exocrine tissue did not produced CB1 (ESM Fig. 2a-c). The few CB2-positive cells in islets were insulin-negative (Fig. 2d-f). Clear CB2 immunostaining was present in exocrine tissue (ESM Fig. 2d). Figure $2 \mathrm{~g}-1$ shows the level of cannabinoid receptor proteins in human alpha cells. Immunostaining patterns of both CB1 and glucagon were nearly identical, suggesting that all alpha cells produce $\mathrm{CB} 1$ (Fig. $2 \mathrm{~g}-\mathrm{i}$ ). In contrast, none of the glucagon-positive cells detected colocalised with CB2, indicating null production of CB2 in alpha cells (Fig. $2 \mathrm{j}-1$ ). Finally, double immunofluorescence with anti-somatostatin and anti-cannabinoid receptors showed that virtually all delta cells produce CB2 (Fig. 2p-r), whereas CB1 immunostaining was nearly absent in this cell subtype (Fig. 2m-o).

CB1 and CB2 as well as the enzymes for synthesis and degradation of endocannabinoids were detected by Western blot analysis in human islets Human islet homogenates 


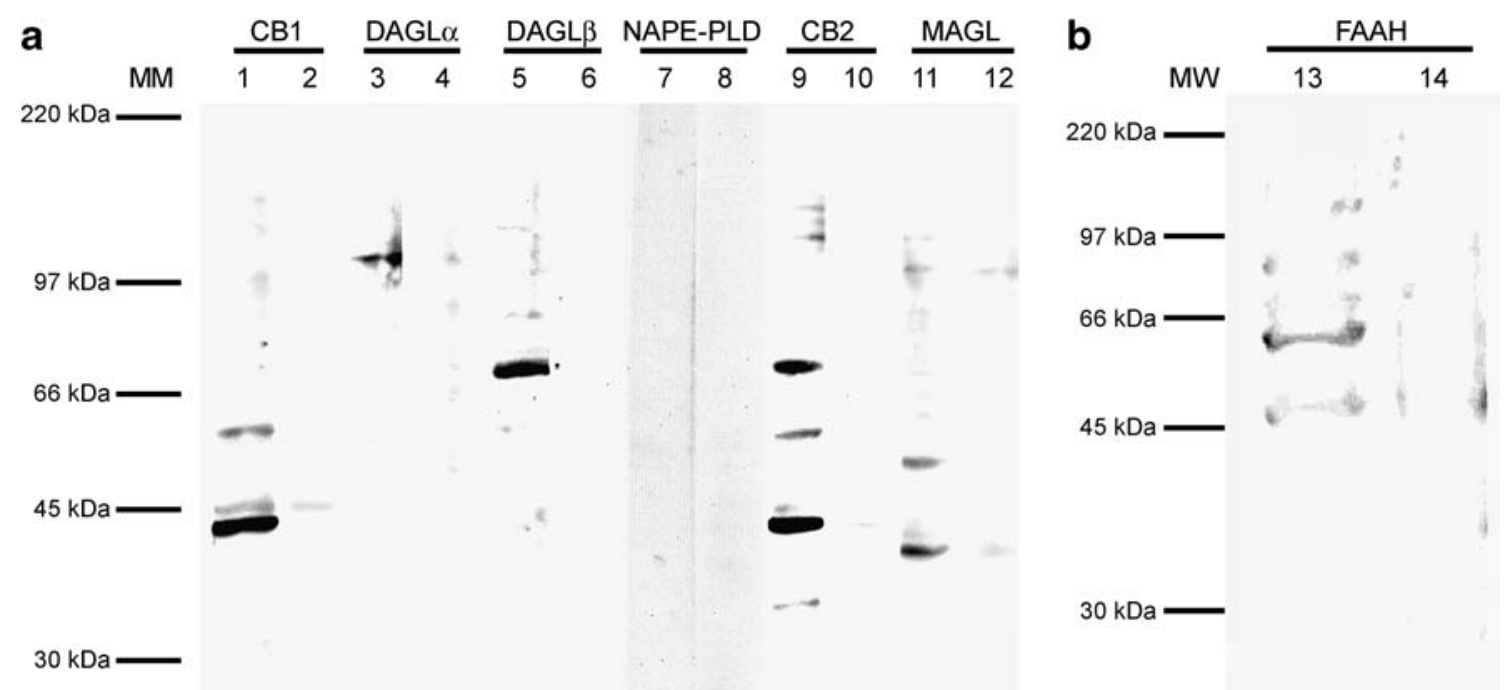

Fig. 3 Western blot analysis of CB1, CB2, NAPE-PLD, DAGL $\alpha$, $\mathrm{DAGL} \beta, \mathrm{FAAH}$ and MAGL. Whole cell lysate was prepared from 1,000 IEQs, solubilised in SDS-dithiothreitol sample buffer, separated in $7.5 \%(w / v)$ polyacrylamide gel, transferred to nitrocellulose and examined by enhanced chemiluminescence analysis for the presence of cannabinoid receptors and the synthesising and degrading enzymes. Molecular mass (MM) markers are shown on the left in $\mathrm{kDa}$ ). As shown a, a strong immunoreactive band at $\sim 43 \mathrm{kDa}$ and a less intense band at $\sim 60 \mathrm{kDa}$ were observed for $\mathrm{CB} 1$ protein (lane 1), consistent with glycosylated and non-glycosylated $\mathrm{CB} 1$ protein described in previous studies [29-32]. Anti-CB2 antibody was reactive for three bands of approximately $\sim 45, \sim 70$ and $\sim 60 \mathrm{kDa}$ (lane 9) that probably reflect glycosylated forms, as previously described [32-34]. Immuno- blots for NAPE-PLD revealed no staining (lane 7); however, a main band with a molecular mass of $\sim 62 \mathrm{kDa}$ could be seen in acinar homogenates (data not shown). DAGL $\alpha$ and DAGL $\beta$ immunoblots showed unique bands of $\sim 120$ and $\sim 70 \mathrm{kDa}$ respectively (lanes 3 and 5 ), identical to those observed previously by Bisogno and collaborators [24]. A major band of $\sim 37 \mathrm{kDa}$ for MAGL protein (lane 11) [35] and $\sim 63 \mathrm{kDa}$ for FAAH protein (lane 13) [36] were detected. Omission of the first antibodies or incubation of the primary antibodies preadsorbed with the corresponding immunising peptides abolished the described bands in lanes 2, 4, 6, 8, 10, 12 (a) and lane 14 (b). The image shows a representative immunoblot of pancreatic islet lysates from three different preparations

glucose-containing wells, $8.71 \pm 0.11 \mathrm{pmol} 2-\mathrm{AG} / \mathrm{mg}$ protein; $3 \mathrm{mmol} / \mathrm{l}$ glucose-containing wells, less than $5.49 \mathrm{pmol}$ 2-AG/mg protein; $n=2$ different experiments, each measured in triplicate.

In vitro stimulation of $C B 1$ and $C B 2$ modifies insulin, glucagon and somatostatin secretion Figure $4 \mathrm{c}$ shows how stimulation of CB1 with both selective (ACEA) and natural (AEA and 2-AG) CB1 agonists increased insulin release from islets cultured under high glucose concentrations. This effect was also observed at low glucose concentrations $(3 \mathrm{mmol} / \mathrm{l})$ and was antagonised by the selective CB1 antagonist AM251 [26] (Fig. 4d). CB2 stimulation with the selective agonist JWH 133 lowered glucose-dependent insulin release (Fig. 4c), an effect mediated by $\mathrm{CB} 2$, since it was found to be antagonised by the selective CB2 antagonist AM630 (data not shown).

CB1 agonism also resulted in stimulation of glucagon secretion (Fig. 5a,b). Both 2-AG and ACEA, but not the CB2 agonist JWH 133, stimulated glucagon release under low glucose culture conditions. The stimulatory effects of ACEA on glucagon secretion were dependent on CB1 stimulation since it was counteracted by incubation with the specific CB1 antagonist AM251 [26] (Fig. 5b).

Regarding somatostatin secretion, we were unable under our experimental conditions to find any specific effect of the 
a

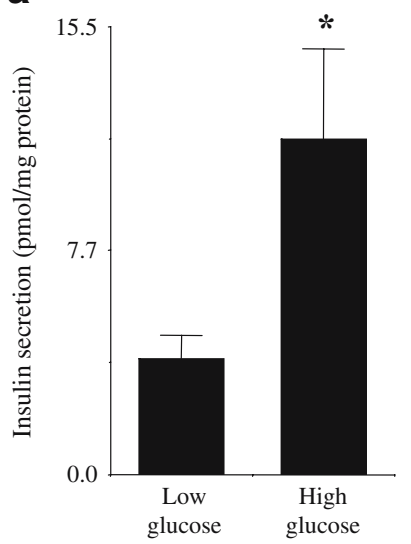

b

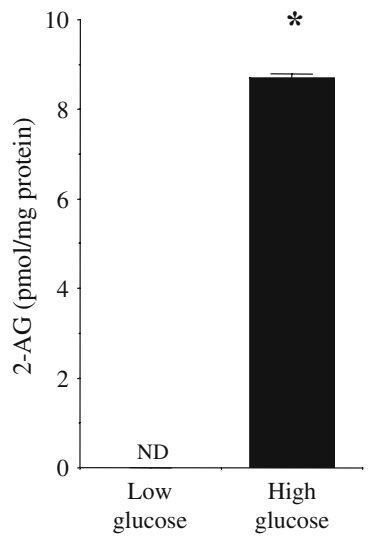

d

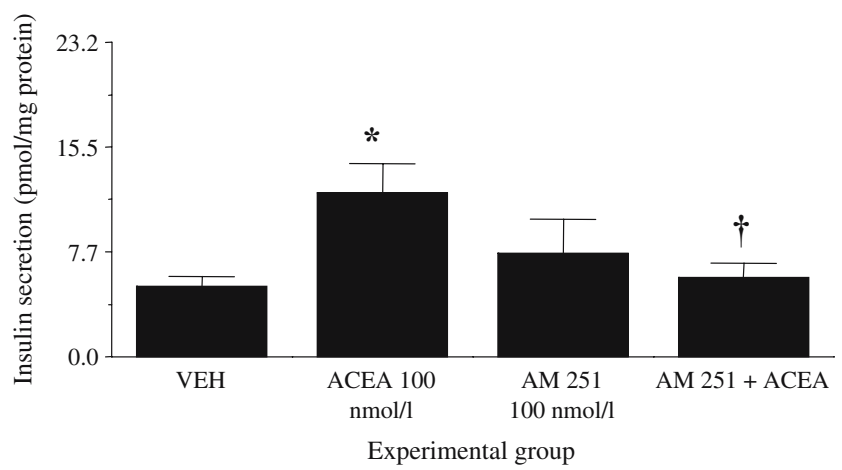

CB2 agonist JWH 133 in islets cultured at $11 \mathrm{mmol} / \mathrm{l}$ glucose (Fig. 5d). However, delta cells from islets incubated at $3 \mathrm{mmol} / \mathrm{l}$ glucose responded to the CB1 agonist ACEA with a potent release of somatostatin (Fig. 5c). Because CB1 are not located in somatostatin cells, the effects of this CB1 agonist on somatostatin are probably derived from the potent stimulation of glucagon and insulin secretion.

The molecular machinery needed to release and process 2$A G$ signalling is present in islets Figure 6 shows the
Fig. 4 Effects of $\mathrm{CB} 1$ or $\mathrm{CB} 2$ agonists on static insulin secretion: functionality of cannabinoid receptors in human islets. Hormone release was investigated by measuring static secretion after addition of either vehicle (VEH), the endocannabinoids 2-AG/AEA or the specific CB1 and CB2 agonists ACEA and JWH-133 (respectively) to human isolated islets kept in vitro for 5 days. a Human islets actively secreted insulin when exposed to a high glucose culture medium $(11 \mathrm{mmol} / \mathrm{l}$ glucose), as compared with basal release at low glucose $(3 \mathrm{mmol} / \mathrm{l})$ concentration in the culture medium. b While 2-AG levels in the islets were not detectable (ND) under low glucose culture conditions, elevation of glucose concentration to $11 \mathrm{mmol} / \mathrm{l}$ increased 2-AG contents. c CB1 agonist ACEA, AEA and 2-AG promoted insulin secretion in a medium that enhances beta cell insulin secretion (supplemented with $11 \mathrm{mmol} / 1$ glucose). Under the same conditions, CB2 activation by JWH-133 significantly decreased insulin release. d The effect of CB1 agonists on insulin secretion was also observed in low glucose medium $(3 \mathrm{mmol} / \mathrm{l})$ where insulin was only released at basal levels. This effect was specific since it was reversed by the CB1 antagonist AM251. Data are means \pm SEM of at least three independent replications each measured in quadruplicate. ${ }^{*} p<0.05$ vs control group; $\dagger p<0.05$ vs ACEA (one way ANOVA with Newman-Keuls as post hoc)

presence of the biosynthetic enzymes NAPE-PLD and DAGL $\alpha$ and the endocannabinoid-degrading enzymes FAAH and MAGL in human islets. Figure 6 a shows the location of Langerhans islets stained with Cromogranin A. An adjacent slide stained with anti-FAAH antibody shows the expression of this enzyme in islets but its absence in acinar tissue (Fig. 6b). MAGL, the other degrading enzyme, was also produced in acinar tissue, although with less intensity than in islets (Fig. 6c). Additional double immunohistochemistry studies localised FAAH enzyme in beta cells but not in alpha cells secreting glucagon (ESM Fig. 3). NAPE-PLD immunoreactivity (Fig. 6d) was almost absent in islets, whereas it was dense in acinar surrounding tissue. We confirmed this by using a different antibody (ESM Fig. 4) and real-time quantitative PCR, which showed very low expression of NAPE-PLD mRNA in isolated pancreatic islets, probably reflecting acinar contamination. The enzymes for the synthesis of 2-AG, DAGL $\alpha$ and DAGL $\beta$ (Fig. 6e,f, respectively) displayed an inverted localisation to NAPE-PLD, being highly produced in islet cells and scarce in acinar tissue. The insert (Fig. 6e) shows a heterogeneous pattern of distribution of DAGL $\alpha$ : some cells within the islet were strongly stained, whereas the remaining lacked immunoreactivity. By contrast, DAGL $\beta$ staining was more homogeneous (insert, Fig. 6f), suggesting that the majority of islet cells express this enzyme to a similar degree. These data suggest that, in the pancreatic islet, the main transmitter is 2-AG, since the machinery for biosynthesis and degradation of this endocannabinoid is present, whereas that of AEA is incomplete. However, since FAAH, the main AEA-degrading enzyme, was densely present in the islet cells secreting insulin, we cannot exclude that extra islet AEA may reach the endocrine cells at sufficient concentrations to produce relevant effects on insulin secretion [35]. 
Fig. 5 Effects of $\mathrm{CB} 1$ or $\mathrm{CB} 2$ agonists on static glucagon and somatostatin secretion. Hormone release was investigated by measuring static secretion after addition of either vehicle (VEH), the endocannabinoids 2-AG or the specific CB1 and CB2 agonists ACEA and JWH133 (respectively) to human isolated islets kept in vitro for 5 days. a Glucagon secretion was dramatically enhanced by CB1 agonists in a glucagonactivating culture medium (low glucose, $3 \mathrm{mmol} / \mathrm{l}$ ), whereas specific $\mathrm{CB} 2$ activation had no effect. b The effects of ACEA on glucagon secretion ( $3 \mathrm{mmol} / \mathrm{l}$ glucose) was also blocked by the specific CB1 antagonist AM251. c Addition of a CB1 agonist to the culture media resulted in a clear stimulation of somatostatin secretion from islets cultured in

$3 \mathrm{mmol} / \mathrm{l}$ glucose. d CB2 activation did not affect somatostatin secretion in $11 \mathrm{mmol} / \mathrm{l}$ glucose. Data are means \pm SEM of at least three independent replications each measured in quadruplicate. ${ }^{*} p<0.05$ vs vehicle; $\dagger p<0.05$ vs ACEA (one-way ANOVA with Newman-Keuls as post hoc)
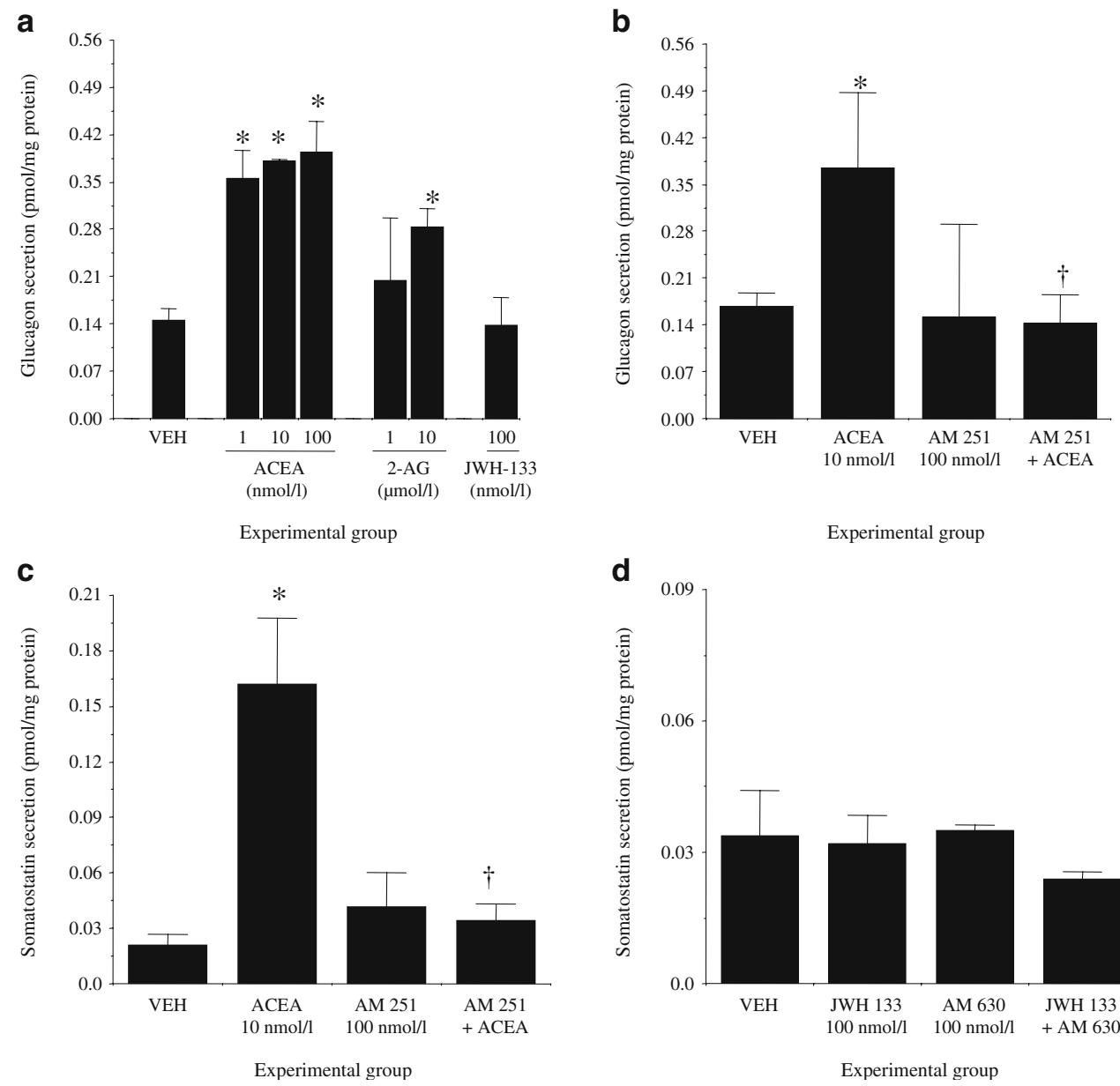

\section{Discussion}

Four major contributions result from this study. First, CB1 and $\mathrm{CB} 2$ are present in human islet cells with a specific distribution. While CB1 are in both alpha and beta cells, CB2 are located in somatostatin-secreting delta cells. In humans, CB2 levels are much lower than CB1 levels throughout the endocrine pancreas. This finding supports the existence of species-specific differences in the distribution of cannabinoid receptors: while mice and rats produced functional CB2 in beta cells, humans do not $[17,19]$. This may be relevant for future analysis of cannabinoid receptordependent actions on islet physiology. Second, while the net effects of CB1 agonists on islet secretion are stimulatory, actions of $\mathrm{CB} 2$ agonists are inhibitory, in agreement with previous studies in rat and mice cells $[17,20]$. CB1 stimulation enhances insulin secretion (both at low and high glucose concentrations). On the other hand, CB2 stimulation reduces insulin secretion, an effect apparently not mediated by somatostatin secretion. Third, at low glucose concentrations, CB1 agonists stimulate glucagon secretion from alpha cells and somatostatin from delta cells. Alpha cells are extremely sensitive to CB1 agonists, since they respond in the nanomolar range. However, the effects of CB1 stimulation on somatostatin secretion are not direct, since delta cells do not produced CB1. This effect is probably mediated through glucagon-dependent somatostatin release, as a negative feedback mechanism, by which tight control of glucagon secretion would be achieved. Finally, analysis of the machinery for biosynthesis and degradation established that in the human pancreatic islet the endocannabinoid synthesised is 2-AG. We deduced this from the fact that both isoforms of DAGL, the enzymes that produce $2-\mathrm{AG}$, were found. The second endocannabinoid, AEA, seems to be produced outside the islets, as we were unable to detect the presence of NAPE-PLD, the main enzyme producing AEA. However, AEA seems to be active in islets because it was found to modulate insulin secretion. Moreover, the islets abundantly produce FAAH, the main AEA-degrading enzyme (ESM Fig. 3). One possibility is that AEA may be transported to the endocrine pancreas by the blood [35]. According to studies in humans and rodents, 

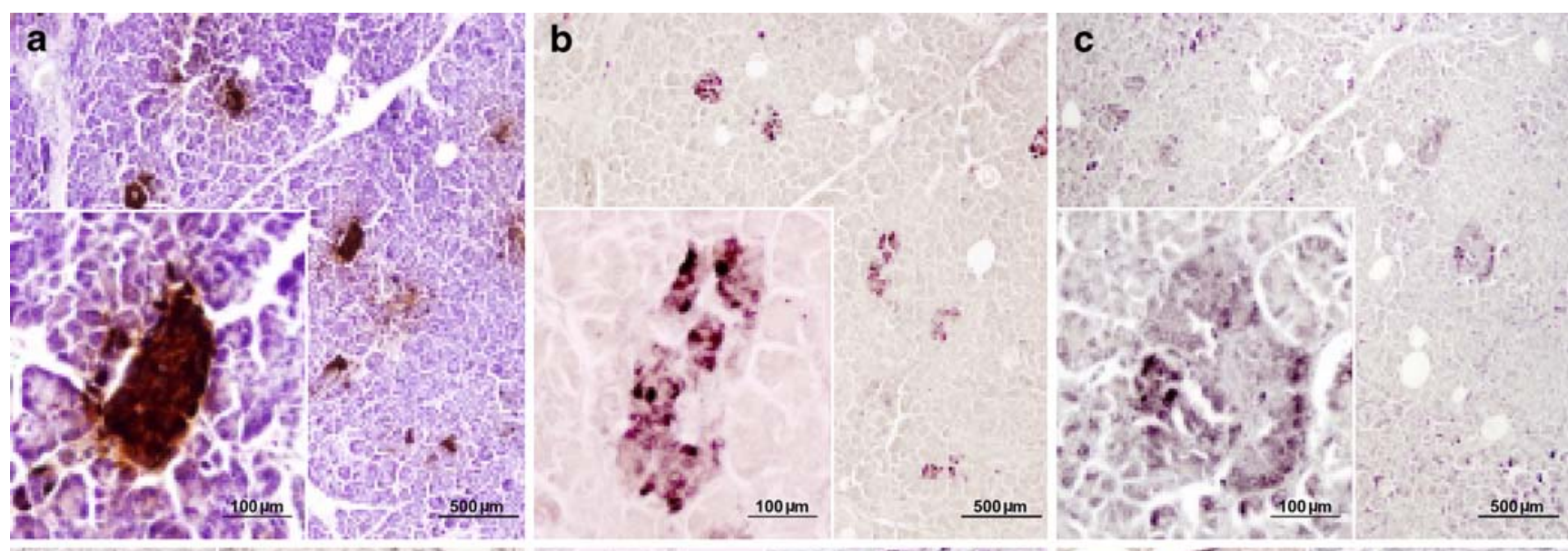

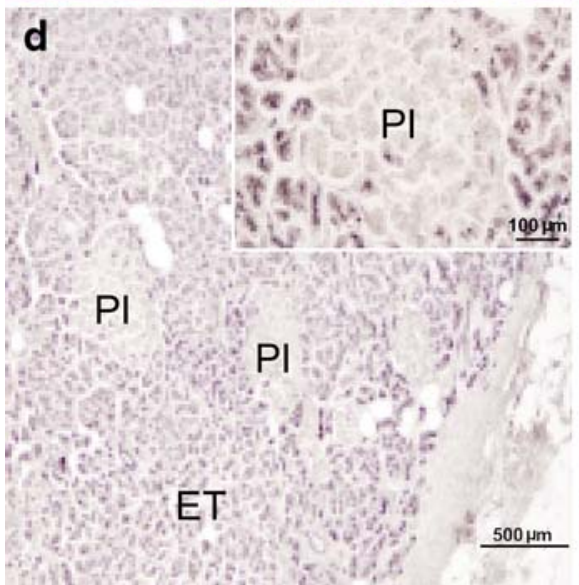

Fig. 6 Protein levels by immunohistochemistry of molecular machinery for the synthesis and degradation of endocannabinoids. Representative photomicrographs of adjacent sections through a human pancreas showing a chromogranin A, b FAAH, c MAGL, d NAPEPLD, e DAGL $\alpha$ and f DAGL $\beta$ indirect immunoperoxidase staining. a General view of a pancreatic area showing numerous islets immunolabelled for chromogranin A. The insert shows a high magnification of a pancreatic islet. b General view of FAAH immunostaining in an adjacent pancreatic area showing numerous islets strongly stained in contrast with acinar tissue. The insert shows immunostaining consisting of a subpopulation of highly stained cells and others with lower labelling. c General view of a pancreatic area showing islets immunopositive for MAGL and a less intense staining in acinar tissue. The insert shows a similar staining pattern to that for FAAH. d Immunostaining for NAPE-PLD. A lack of immunoreactivity in the pancreatic islets can be seen, but NAPE-PLD levels in the exocrine tissue are high. ET, exocrine tissue; PI, pancreatic islet. e DAGL $\alpha$ immunostaining in a pancreatic islet. Some cells within the islet are strongly stained, whereas the remainder lack immunoreactivity. f DAGL $\beta$ immunoreactivity in a pancreatic islet. The insert shows more homogeneous staining than for DAGL- $\alpha$, suggesting that the majority of islet cells produce DAGL $\beta$ elevated circulating levels of AEA result in hyperglycaemia, insulin resistance and elevated insulin levels through its multiple actions in the pancreatic islets, the adipose tissue and the liver [13, 18, 19, 36 and present results].

Overall, the present study suggests that intra-islet 2-AG production may serve as a local modulator of insulin and glucagon secretion in cells producing CB1 and CB2. 2-AG may be degraded in the islet, since we found relevant production of MAGL enzyme. This hypothesis is supported by the finding of $2-\mathrm{AG}$ in the islets and by the relevant modulation that glucose concentration exerted on its intracellular levels. Our observation is in agreement with a previous report in rat insulinoma cells [20] and correlates with the 2-AG-dependent insulin secretion found in islets cultured under high glucose concentrations. Disappearance of 2-AG from islets under low glucose concentrations can be interpreted as a removal of a stimulatory signal needed for insulin secretion. Stimulation of CB1 under this low glucose condition is able to promote insulin release, but this response is associated with a potent counter-regulatory glucagon secretion.

The effects on insulin and glucagon secretion that were observed after CB1 stimulation are both stimulatory, indicating a desynchronisation of both types of cells. One potential explanation is the pleiotropic actions of AEA in the endocrine pancreas, as described in rodent islet cells [17]. In these cells almost one third of the beta cells stimulated with AEA showed opposite patterns of calcium oscillation coupled to insulin secretion, indicating multiple mechanisms of action ([17]; A. Nadal and P. Juan-Picó, 
unpublished results). Additional mechanisms may be the interference induced by AEA on GAP junctions [37] involved in electrical beta cell coupling [38]. However, the fact that the selective blockade of CB1 with AM251 attenuated the stimulation of both insulin and glucagon secretion supports a more relevant contribution of the CB1.

Finally, we found that CB2 are located in somatostatinsecreting cells. Since this peptide is a potent intra-islet modulator of insulin and glucagon secretion [39], it is feasible to expect somatostatin-dependent responses to cannabinoid receptor agonists. Under our experimental conditions, CB2 activation did not change somatostatin secretion in $11 \mathrm{mmol} / \mathrm{l}$ glucose, suggesting that CB2dependent inhibition of insulin secretion is not related to CB2-induced somatostatin release. Further research is needed to clarify the role of this receptor in delta cells.

After consideration of all the findings in this study and placing them within the context of endocannabinoid physiology, we propose a major role for CB1 and 2-AG in the regulation of islet physiology and energy homeostasis. $\mathrm{CB} 1$ stimulation was able to increase insulin and glucagon secretion, as well as lipogenesis in liver and adipose tissue, while it blocked the incorporation of glucose into the muscle cells, leading to a 'saving cycle': reduced energy expenditure and increased energy storage $[6,7,12,13]$. Enhanced insulin release may help to facilitate the incorporation of glucose into adipocytes, while enhanced glucagon release may sustain high plasma glucose levels, favouring this 'saving cycle'. Under this hypothesis, CB1 can be considered a new 'thrifty gene'. Its physiological and pharmacological profile is strikingly similar to that of the $\mu$-opioid receptor, a recently proposed contributor to the 'saving cycle' [40] and a major partner of CB1 signalling in the brain [41]. In light of this potential role, and supported by clinical trials using the CB1 antagonist, the endocannabinoid system can be considered a promising target for pharmacological development in diabetes and complicated obesity.

Acknowledgements This study was supported by Consejerias de Salud e Innovación, Junta de Andalucia (SAS 144/04 and SAS 0064/ 05), Instituto de Salud Carlos III (grants 03/0178, 07/0880 and 07/ 1226), Redes Temáticas ISCIII-RETIC RD06/001 and RD06/0015/ 008 and MEC (grants SAF 2004-07762, SAF 2005-08014, SAF 200612863, BFU2005-01052). P. Juan-Pico has a PhD scholarship from Instituto de Salud Carlos III. G. Milman was supported by US National Institute on Drug Abuse. The authors are grateful to: J. M. Mellado (Human Islet Isolation Facility, Carlos Haya Hospital, Malaga, Spain) for kindly helping in human islet isolation; D. Piomelli (Department of Pharmacology, University of California, Irvine, CA, USA) for providing rabbit anti-MAGL and anti-NAPEPLD; J. Romero (Research laboratory, Fundacion Hospital Alcorcon, Madrid, Spain) and K. Mackie (Department of Psychiatry and Brain Sciences, Indiana University, Bloomington, IN, USA) for kindly donating CB1 and CB2 blocking peptides; I. Sanchez (Regenerative Medicine Laboratory, IMABIS Foundation, Malaga, Spain) for technical assistance; J.C. Aledo (Department of Biochemistry and Molecular Biology, University of Malaga, Spain) for helping in antibodies generation; and A. Garcia-Ocaña (Division of Endocrinology, University of Pittsburgh, PA, USA) for initial support in immunohistochemistry.

Duality of interest The authors declare that there is no duality of interest associated with this manuscript.

\section{References}

1. Devane WA, Dysarz FA 3rd, Johnson M, Melvin LS, Howlett AC (1998) Determination and characterization of a cannabinoid receptor in rat brain. Mol Pharmacol 34:605-613

2. Devane WA, Hanus L, Breuer A et al (1992) Isolation and structure of a brain constituent that binds to the cannabinoid receptor. Science 258:1946-1949

3. Stella N, Schweitzer P, Piomelli D (1992) A second endogenous cannabinoid that modulates long-term potentiation. Nature 388:773-778

4. Mechoulam R, Ben-Shabat S, Hanus L et al (1995) Identification of an endogenous 2-monoglyceride, present in canine gut, that binds to cannabinoid receptors. Biochem Pharmacol 50:83-90

5. Piomelli D (2003) The molecular logic of endocannabinoid signalling. Nat Rev Neurosci 4:873-884

6. Di Marzo V, Matias I (2005) Endocannabinoid control of food intake and energy balance. Nat Neurosci 8:585-589

7. Cota D, Marsicano G, Tschop M et al (2003) The endogenous cannabinoid system affects energy balance via central orexigenic drive and peripheral lipogenesis. J Clin Invest 112:423-431

8. Gomez R, Navarro M, Ferrer B et al (2002) A peripheral mechanism for $\mathrm{CB} 1$ cannabinoid receptor-dependent modulation of feeding. J Neurosci 22:9612-9617

9. Kirkham TC, Williams CM, Fezza F, Di Marzo V (2002) Endocannabinoid levels in rat limbic forebrain and hypothalamus in relation to fasting, feeding and satiation: stimulation of eating by 2-arachidonoyl glycerol. Br J Pharmacol 136:550-557

10. Di Marzo V, Goparaju SK, Wang L et al (2001) Leptin-regulated endocannabinoids are involved in maintaining food intake. Nature 410:822-825

11. Pavon FJ, Bilbao A, Hernandez-Folgado L et al (2006) Antiobesity effects of the novel in vivo neutral cannabinoid receptor Antagonist 5-(4-chlorophenyl)-1-(2,4-dichlorophenyl)-3-hexyl1H-1,2,4-triazole-LH 21. Neuropharmacology 51:358-366

12. Osei-Hyiaman D, DePetrillo M, Pacher P et al (2005) Endocannabinoid activation at hepatic $\mathrm{CB} 1$ receptors stimulates fatty acid synthesis and contributes to diet-induced obesity. J Clin Invest 115:1298-1305

13. Engeli S, Bohnke J, Feldpausch M et al (2005) Activation of the peripheral endocannabinoid system in human obesity. Diabetes 54:2838-2843

14. Van Gaal LF, Rissanen AM, Scheen AJ, Ziegler O, Rossner S, RIO-Europe Study Group (2005) Effects of the cannabinoid-1 receptor blocker rimonabant on weight reduction and cardiovascular risk factors in overweight patients: 1-year experience from the RIO-Europe study. Lancet 365:1389-1397

15. Pi-Sunyer FX, Aronne LJ, Heshmati HM, Devin J, Rosenstock J, RIO-North America Study Group (2006) Effect of rimonabant, a cannabinoid-1 receptor blocker, on weight and cardiometabolic risk factors in overweight or obese patients: RIO-North America: a randomized controlled trial. JAMA 295:761-775 
16. Scheen AJ, Finer N, Hollander P, Jensen MD, Van Gaal LF, RIODiabetes Study Group (2006) Efficacy and tolerability of rimonabant in overweight or obese patients with type 2 diabetes: a randomised controlled study. Lancet 368:1660-1672

17. Juan-Pico P, Fuentes E, Bermúdez-Silva FJ et al (2006) Cannabinoid receptors regulate $\mathrm{Ca} 2+$ signals and insulin secretion in pancreatic $\beta$-cells. Cell Calcium 39:155-162

18. Bermudez-Silva FJ, Serrano A, Diaz-Molina FJ et al (2006) Activation of cannabinoid CB1 receptors induces glucose intolerance in rats. Eur J Pharmacol 531:282-284

19. Bermudez-Silva FJ, Suarez J, Sanchez Vera I et al (2007) Role of cannabinoid $\mathrm{CB}_{2}$ receptors in glucose homeostasis in rats. Eur $\mathbf{J}$ Pharmacol 565:207-211

20. Matias I, Gonthier MP, Orlando P et al (2006) Regulation, function and dysregulation of endocannabinoids in models of adipose and beta-pancreatic cells and in obesity and hyperglycemia. J Clin Endocrin Metab 91:3171-3180

21. Ricordi C, Lacy PE, Finke EH, Olack BJ, Scharp DW (1988) Automated method for isolation of human pancreatic islets. Diabetes 37:413-420

22. Cuesta-Munoz AL, Briones RM, Mellado-Gil JM et al (2005) Internal assessment of a novel islet isolation facility in Spain. Transplant Proc 37:3404-3406

23. Hansson AC, Bermudez-Silva FJ, Malinen H et al (2007) Genetic impairment of frontocortical endocannabinoid degradation and high alcohol preference. Neuropsychopharmacology 32:117-126

24. Hillard CJ, Manna S, Greenberg MJ et al (1999) Synthesis and characterization of potent and selective agonists of the neuronal cannabinoid receptor (CB1). J Pharmacol Exp The 289:1427-1433

25. Huffman JW, Liddle J, Yu S et al (1999) 3-(1',1'-Dimethylbutyl)1-deoxy-delta8-THC and related compounds: synthesis of selective ligands for the CB2 receptor. Bioorg Med Chem 7:29052914

26. Gatley SJ, Lan R, Pyatt B, Gifford AN, Volkow ND, Makriyannis A (1997) Binding of the non-classical cannabinoid CP 55,940, and the diarylpyrazole AM251 to rodent brain cannabinoid receptors. Life Sci 61:PL191-PL197

27. Pettit DAD, Harrison MP, Olson JM et al (1998) Immunohistochemical localization of the neural cannabinoid receptor in rat brain. J Neurosci Methods 51:391-402

28. Egertová M, Elphick MR (2000) Localisation of cannabinoid receptors in the rat brain using antibodies to the intracellular Cterminal tail of CB1. J Comp Neurol 422:159-171
29. Ashton JC, Zheng Y, Liu P et al (2004) Immunohistochemical characterisation and localisation of cannabinoid CB1 receptor protein in the rat vestibular nucleus complex and the effects of unilateral vestibular deafferentation. Brain Res 1021:264-271

30. Roche R, Hoareau L, Bes-Houtmann S et al (2006) Presence of the cannabinoid receptors, $\mathrm{CB} 1$ and $\mathrm{CB} 2$, in human omental and subcutaneous adipocytes. Histochem Cell Biol 126:177-187

31. Van Sickle MD, Duncan M, Kingsley PJ et al (2005) Identification and functional characterization of brainstem cannabinoid CB2 receptors. Science 310:329-332

32. Gong JP, Onaivi ES, Ishiguro $H$ et al (2006) Cannabinoid CB2 receptors: Immunohistochemical localization in rat brain. Brain Res 1071:10-23

33. Dinh TP, Carpenter D, Leslie FM et al (2002) Brain monoglyceride lipase participating in endocannabinoid inactivation. Proc Natl Acad Sci U S A 99:10819-10824

34. Cravatt BF, Giang DK, Mayfield SP et al (1996) Molecular characterization of an enzyme that degrades neuromodulatory fatty-acid amides. Nature 384:83-87

35. Giuffrida A, Rodriguez de Fonseca F, Nava F, Loubet-Lescoulie P, Piomelli D (2000) Elevated circulating levels of anandamide after administration of the transport inhibitor, AM404. Eur J Pharmacol 408:161-168

36. Pagotto U, Marsicano G, Cota D, Lutz B, Pasquali R (2005) The emerging role of the endocannabinoid system in endocrine regulation and energy balance. Endocr Rev 27:73-100

37. Venance L, Piomelli D, Glowinski J, Giaume C (1995) Inhibition by anandamide of gap junctions and intercellular calcium signalling in striatal astrocytes. Nature 376:590-594

38. Ravier MA, Guldenagel M, Charollais A et al (2005) Loss of connexin36 channels alters beta-cell coupling, islet synchronization of glucose-induced $\mathrm{Ca} 2+$ and insulin oscillations, and basal insulin release. Diabetes 54:1798-1807

39. Singh V, Brendel MD, Zacharias S et al (2007) Characterization of somatostatin receptor subtype-specific regulation of insulin and glucagon secretion: an in vitro study on isolated human pancreatic islets. J Clin Endocrinol Metab 92:673-680

40. Tabarin A, Diz-Chaves Y, Carmona M del C et al (2005) Resistance to diet-induced obesity in mu-opioid receptor-deficient mice: evidence for a "thrifty gene". Diabetes 54:3510-3516

41. Cota D, Tschop MH, Horvath TL, Levine AS (2006) Cannabinoids, opioids and eating behavior: the molecular face of hedonism? Brain Res Rev 51:85-107 